\title{
Article
}

\section{Using Literature and Innovative Assessments to Ignite Interest and Cultivate Critical Thinking Skills in an Undergraduate Neuroscience Course}

\author{
Eileen Lynd-Balta
}

\author{
Department of Biology, St. John Fisher College, Rochester, NY 14618
}

Submitted August 31, 2005; Revised February 21, 2006; Accepted March 1, 2006

Monitoring Editor: Deborah Allen

\begin{abstract}
Science education reform initiatives emphasize 1) the value of concepts over facts; 2) the benefits of open-ended, inquiry-based problem-solving rather than protocols leading to a single correct answer; and 3) the importance of a multidisciplinary approach to teaching that is not confined by departmental boundaries. Neuroscientists should be at the forefront of this movement by the very nature of the discipline we study. Neuroscience is a relatively new field that integrates diverse subjects (anatomy, physiology, pharmacology, molecular biology, computer science, and psychology) and experimental advances are constantly changing and expanding our understanding of brain function. How can we convey this excitement in the classroom? The project described in this article uses nonscientific literature to introduce a scientific topic of study. In addition, the multitask assignment requires the acquisition of content knowledge and the development of critical thinking skills. As students explore the topic from multiple perspectives, they recognize the interconnectedness of science and society and confront ethical and moral issues related to science. A comparison of exam scores, essay responses, engagement level, as well as students' own reflections, demonstrates that inclusion of the project does not sacrifice content knowledge, rather it enhances the overall learning process.
\end{abstract}

\section{INTRODUCTION}

Introductory neuroscience courses are typically an interdisciplinary exploration of the structure and function of the nervous system at chemical, cellular, circuit, and systems levels of organization. Students learn mechanisms of brain function underlying such complex processes as movement, sensory processing, cognition, and behavior. In addition, and perhaps of more interest to the student, is the examination of what goes wrong in neurological disorders.

According to Bloom's Taxonomy of Educational Objectives (Bloom and Krathwohl, 1956; Krathwohl et al., 1964), we must strive to create learning environments that give students opportunities to apply, analyze, synthesize, and evaluate information. Only when students actively process information in this way do they attain a true understanding of the topic (Wiggins and McTighe, 2005). Such critical thinking skills transcend disciplines; nevertheless, their impor-

DOI: $10.1187 /$ cbe. $05-08-0108$

Address correspondence to: Eileen Lynd-Balta (elynd-balta@ sjfc.edu). tance to developing a meaningful comprehension of experimental science is obvious. In recent years, partly because of pressure from accrediting bodies, a culture of evidence has evolved such that defining and subsequently monitoring assessable criteria of student learning are considered integral components of any successful academic program (American Association for Higher Education, 1992; Angelo, 1995; Heady, 2000).

Because learning outcomes are articulated by institutions/ departments/course instructors, it becomes clear that scientific knowledge should be taught in a relevant context that explores real-life issues. Students, regardless of major, need to understand that science 1) is interconnected with other disciplines, 2) has ethical implications, and 3) must be used to make informed decisions that impact individuals and society. Hobson (2001) argues that making science courses more socially and culturally relevant is a critical component to educating undergraduates to be scientifically literate. This relevance can be brought into the classroom with hypothetical and/or real-world problem-solving scenarios. For example, service learning, when students apply content knowledge to assist in some way in their community, has become 
a successful pedagogical technique (Battistoni, 1995). Ultimately, a good foundation in content knowledge and the development of critical thinking skills are essential for lifelong learners.

The multifaceted assignment described in this article uses nonscientific literature to enrich a scientific topic of focus. I have used it successfully in an undergraduate neuroscience course designed for biology majors, although it could be easily adapted for many science courses. It involves reading assignments, a reaction essay, and the production of an informational pamphlet. This pedagogical technique was instrumental in providing the impetus for students to seek understanding of nervous system function, appreciate the interdisciplinary nature of science, and grapple with the ethical implications of scientific discoveries. The project was woven into course readings, discussions, and assessment and effectively reinforced and enhanced the content knowledge while requiring students to be both analytical and reflective thinkers.

\section{PROJECT DESIGN}

As part of a college-wide initiative, the faculty at St. John Fisher College have been working on articulating broad program goals and assessable learning outcomes as well as collecting evidence to measure student success. Analysis of these data can then be the impetus for informed positive pedagogical change. Goals defined by individual departments align with the college's overall mission, which emphasizes the value of a liberal arts education. An example of a goal and associated outcomes developed by our biology department is provided in the Supplemental Material. It is the responsibility of individual faculty members to incorporate a subset of these outcomes in their courses. The neurobiology course I teach is a one-semester upper-level elective course for biology majors. I include both course goals and more specific learning outcomes on the first page of the syllabus (Figure 1; the full syllabus is provided in Supplemental Material). Many of the outcomes are driven by content specific to the course; however, others are aimed at developing critical thinking skills.

Despite the fact that science faculty would agree that ethical and moral issues related to science are of great importance, most undergraduate science courses focus on content, with little or no emphasis on the complex interplay between science and society. Although I was confident that the more content-specific learning outcomes could be assessed on existing homework assignments and exam questions, I wanted to provide some opportunities for students to hone their critical thinking skills and to explore the interactions of science and society as well ethical and moral questions relating to scientific advances. I developed a project to incorporate several of the learning outcomes and to provide some alternative assessment techniques. There are several components to this semester-long project. By carefully planning the timing of different aspects of the project, I maximized the opportunities for students to acquire new information, link it to existing knowledge, and then synthesize a unique product.

With the learning outcomes identified, my next tasks were to decide on a topic of focus and to select a piece of literature
Course Description

This course is designed to introduce students to the field of neurobiology. We will examine the structure and function of the nervous system using an interdisciplinary approach. Information processing in the brain is considered at the molecular, cellular, circuit, and system levels of organization. Disorders of the nervous system are also explored. The course is designed for biology majors and requires students to attend and actively participate in class each week.

Prerequisites: BIOL $128 \mathrm{C} \& 311$ or permission of the instructor.

Course Goals

- To understand and apply scientific concepts to explain and predict normal function as well as dysfunction of the nervous system.

- To further stimulate your interest and curiosity in neurobiology.

Learning Outcomes:

Students who successfully complete this course will be able to:

- Demonstrate proficiency in the correct usage of scientific terminology.

- Explain anatomical, physiological, pharmacological, and molecular properties of neurons and apply this information to examine electrical signaling and interneuron communication.

- Describe the organization of the nervous system and visually identify major landmarks, subdivisions, fiber tracts, and nuclei of the nervous system.

- Illustrate the pathways associated with somatic sensation and voluntary movement.

- Interpret links between brain function and behaviors.

- Interpret links between brain function and behaviors. effectively answer experimental questions related to neural function.

- Recognize the interaction of science and society and identify and evaluate the moral and ethical dimensions of biological problems

- Demonstrate precise, objective communication skills for reporting and interpreting scientific information.

Figure 1. Course goals and student learning outcomes. Goals and outcomes are clearly delineated on the course syllabus (full syllabus provided in Supplemental Material).

that would supplement the content. Here, the term literature is used in its broadest definition and it is left to the discretion of individual instructors to determine what can best serve as the catalyst for student learning. In the written form, it could be works of fiction or nonfiction, poetry, essays, and short stories. It does not have to be limited to the written word because there are many films, plays, and artwork that could serve as the springboard for further study. Viewing a film together can stimulate immediate discussion and debate. Interpreting the meaning of a relevant poem or a piece of art forces students to appreciate the interdisciplinary nature of learning. The majority of students are young and healthy, so it is particularly effective to use literature before studying a particular disease/condition/dysfunction, because most students have little or no experience with it. Because this project was going to span the entire semester and would require a more in-depth exploration of a topic, I decided to have the students read a book. I chose to focus on the neurodegenerative disorder amyotrophic lateral sclerosis (ALS; Lou Gehrig's disease) and have the students read Tuesdays with Morrie: An Old Man, A Young Man, and Life's Greatest Lesson by Mitch Albom (Albom, 1997).

Once I identified the literature to be used, I created a timeline for the project that aligned with the presentation of related course material and I included this information on the syllabus. There are three main elements to the project: 1 ) read/view the selected literature, 2) react to the literature in a short essay, and 3) create an informational pamphlet on the topic/condition/disease dealt with in the literature that is subsequently studied from a scientific perspective (Figure 2). I set a deadline for reading the book $1 \mathrm{wk}$ before when we were to begin studying the motor system. The story added some personal/emotional context to the motor system topic for the students. By completing the literature assignment in advance, it served as a catalyst for learning the underlying physiology, pharmacology, and anatomy that elucidates both normal function and dysfunction. The essay was due 1 


\section{Assignment: 3 Components}

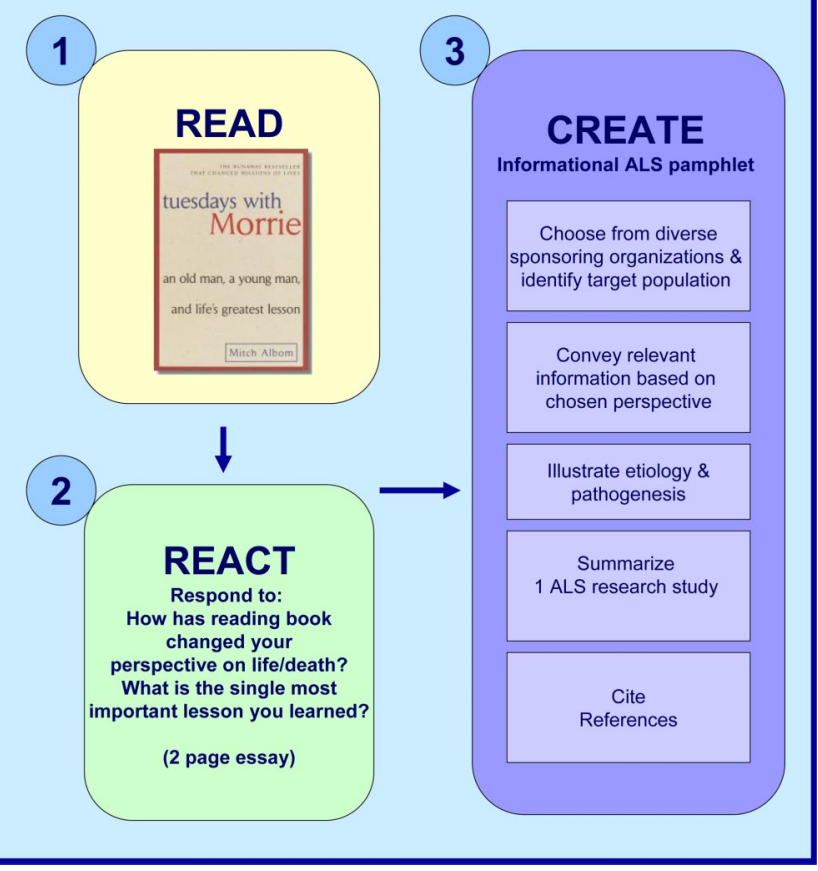

Figure 2. Three components of the multifaceted project. The project requires students to approach a topic from multiple perspectives. The innovative assessments address diverse learning outcomes and promote analytical and reflective thinking.

wk later, as we began our exploration of the motor system. I provided focus questions for students to respond to the literature in a reaction essay. Completion of the essay was one indicator that students were prepared for in-class discussions and collaborative work on the topic. The due date for the informational pamphlet was several weeks later, after students had gained the necessary scientific knowledge to thoughtfully synthesize ideas, evaluate data, and effectively communicate information. During this time, I crafted in-class and out-of-class activities that provided the appropriate scaffolding to students, i.e., text reading, class discussion, lecture topics, and problem-solving exercises, to support each student's efforts.

In my experience, information included in a course syllabus can be overwhelming to students, so I chose to communicate more detailed instructions about each component of the project in a separate document that we reviewed as a class 2 wk into the semester (ALS Project Instructions, see Supplemental Material). However, information about the project was included in the following sections of the course syllabus: Required Textbooks, Grading, and Schedule of Assignments (Syllabus, see Supplemental Material). I clearly articulated in the course syllabus how the project grade contributed to the overall course grade. I used weighted percentages such that the project was equivalent to one exam (there are three exams during the semester, plus a cumulative final). In addition, a weighted percentage of a student's engagement grade also contributes to the final course grade (again equivalent to one exam grade), and so activities related to the project, for example, in-class discussions, represented additional credit that a student could earn.

The content-rich science component of the project was the creation of an informational pamphlet for which I provided explicit instructions. Although there was a single topic that all students were to address, i.e., ALS, the assignment was crafted in a way to make each project unique. Students chose a sponsoring organization for their pamphlet and identified their target population. Examples were provided to the students, but they were urged to consider their interests. Students had to convey relevant information based on their chosen perspective. All students needed to include essentials about the etiology and pathogenesis of the disease, but depending on the perspective chosen, each student would illustrate this information differently. In addition, students were required to do a literature search, select a journal article from a peer-reviewed journal, and incorporate a succinct and effective summary of the study in the pamphlet. Students also submitted a bibliography of their sources.

Along with detailed instructions for the project, I provided an explanation for how and when assessment would take place. Furthermore, I conveyed how the project components aligned with specific learning outcomes (Figure 3) (Lynd-Balta et al., 2006). If an instructor clearly articulates the outcomes from the outset, it can help reduce the anxiety some students may have for the nontraditional assignment. A rubric used for assessing the pamphlet is illustrated in Figure 4. Students were encouraged to consult the rubric and use it as a guide as they worked on their projects. A rubric is a particularly useful tool to convey the significance of particular instructions (Montgomery, 2002). A rubric can be prepared using RubiStar, a free online service to teachers

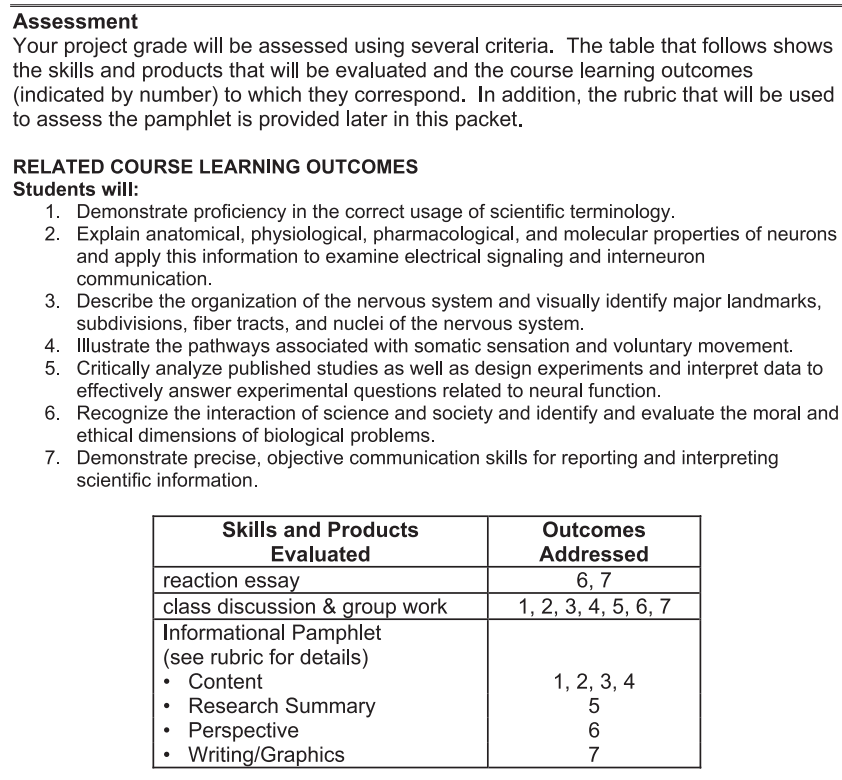

Figure 3. Alignment of learning outcomes with assessment. How each component of the project aligns with specific learning outcomes is clearly articulated in the project instructions (full instructions provided in Supplemental Material). 


\begin{tabular}{|c|c|c|c|c|}
\hline \multicolumn{5}{|c|}{ ALS Brochure/Pamphlet Rubric } \\
\hline CATEGORY & A & B & C & D \\
\hline $\begin{array}{l}\text { Content - } \\
\text { Accuracy }\end{array}$ & $\begin{array}{l}\text { All facts in the } \\
\text { brochure are accurate. }\end{array}$ & $\begin{array}{l}99-90 \% \text { of the facts in } \\
\text { the brochure are } \\
\text { accurate. }\end{array}$ & $\begin{array}{l}89-80 \% \text { of the facts in } \\
\text { the brochure are } \\
\text { accurate. }\end{array}$ & $\begin{array}{l}\text { Fewer than } 80 \% \text { of the } \\
\text { facts in the brochure } \\
\text { are accurate. }\end{array}$ \\
\hline $\begin{array}{l}\text { Research } \\
\text { Summary }\end{array}$ & $\begin{array}{l}\text { Clear \& succinct } \\
\text { summary of recent } \\
\text { scientific study is } \\
\text { provided along with an } \\
\text { explanation of the } \\
\text { significance of the } \\
\text { study. }\end{array}$ & $\begin{array}{l}\text { Summary of recent } \\
\text { scientific study and its } \\
\text { significance includes } \\
\text { main points, but } \\
\text { misses some important } \\
\text { details. }\end{array}$ & $\begin{array}{l}\text { Summary of recent } \\
\text { scientific study and its } \\
\text { significance is } \\
\text { inaccurate or difficult to } \\
\text { understand. }\end{array}$ & $\begin{array}{l}\text { Little or no summary of } \\
\text { scientific study is } \\
\text { provided. Significance } \\
\text { of study is not } \\
\text { articulated. Study is } \\
\text { not published in peer- } \\
\text { reviewed journal. }\end{array}$ \\
\hline $\begin{array}{l}\text { Sponsoring } \\
\text { Organization }\end{array}$ & $\begin{array}{l}\text { Sponsoring } \\
\text { organization \& target } \\
\text { population clearly } \\
\text { identified. ALS } \\
\text { information presented } \\
\text { is salient to sponsor } \\
\text { \&/or target. }\end{array}$ & $\begin{array}{l}\text { Sponsoring } \\
\text { organization \& target } \\
\text { population clearly } \\
\text { identified. ALS } \\
\text { information presented } \\
\text { is not specific to } \\
\text { sponsor \&/or target. }\end{array}$ & $\begin{array}{l}\text { Sponsoring } \\
\text { organization or target } \\
\text { population not clearly } \\
\text { identified. ALS } \\
\text { information presented } \\
\text { is not specific to } \\
\text { sponsor \&/or target. }\end{array}$ & $\begin{array}{l}\text { Sponsoring } \\
\text { organization and target } \\
\text { population not clearly } \\
\text { identified. }\end{array}$ \\
\hline $\begin{array}{l}\text { Organization \& } \\
\text { Originality }\end{array}$ & $\begin{array}{l}\text { The brochure has } \\
\text { exceptionally attractive } \\
\text { formatting and well- } \\
\text { organized information. }\end{array}$ & $\begin{array}{l}\text { The brochure has } \\
\text { attractive formatting } \\
\text { and well-organized } \\
\text { information. }\end{array}$ & $\begin{array}{l}\text { The brochure has well- } \\
\text { organized information. }\end{array}$ & $\begin{array}{l}\text { The brochure's } \\
\text { formatting and } \\
\text { organization of } \\
\text { material are confusing } \\
\text { to the reader. }\end{array}$ \\
\hline $\begin{array}{l}\text { Graphics/ } \\
\text { Pictures }\end{array}$ & $\begin{array}{l}\text { Graphics go well with } \\
\text { the text and there is a } \\
\text { good mix of text and } \\
\text { graphics. Graphics are } \\
\text { original. }\end{array}$ & $\begin{array}{l}\text { Some non-original } \\
\text { graphics used. }\end{array}$ & $\begin{array}{l}\text { Graphics go well with } \\
\text { the text, but there are } \\
\text { too few and the } \\
\text { brochure seems "text- } \\
\text { heavy". }\end{array}$ & $\begin{array}{l}\text { Graphics do not go } \\
\text { with the accompanying } \\
\text { text or appear to be } \\
\text { randomly chosen. } \\
\text { Graphics are copied } \\
\text { from source. }\end{array}$ \\
\hline $\begin{array}{l}\text { Writing - } \\
\text { Organization }\end{array}$ & $\begin{array}{l}\text { Each section in the } \\
\text { brochure has a clear } \\
\text { beginning, middle, and } \\
\text { end. There are no } \\
\text { grammatical mistakes } \\
\text { nor spelling errors in } \\
\text { the brochure. }\end{array}$ & $\begin{array}{l}\text { Almost all sections of } \\
\text { the brochure have a } \\
\text { clear beginning, middle } \\
\text { and end. There are no } \\
\text { more than two } \\
\text { grammatical mistakes/ } \\
\text { spelling errors in the } \\
\text { brochure. }\end{array}$ & $\begin{array}{l}\text { Most sections of the } \\
\text { brochure have a clear } \\
\text { beginning, middle and } \\
\text { end. There are no } \\
\text { more than } 4 \\
\text { grammatical mistakes/ } \\
\text { spelling errors in the } \\
\text { brochure. }\end{array}$ & $\begin{array}{l}\text { Less than half of the } \\
\text { sections of the } \\
\text { brochure have a clear } \\
\text { beginning, middle and } \\
\text { end. There are no } \\
\text { more than } 6 \\
\text { grammatical mistakes/ } \\
\text { spelling errors in the } \\
\text { brochure. }\end{array}$ \\
\hline Bibliography & $\begin{array}{l}\text { At least } 4 \text { references, } 2 \\
\text { in peer-reviewed } \\
\text { journals, were used } \\
\text { and correctly cited. }\end{array}$ & $\begin{array}{l}\text { At least } 4 \text { references, } 1 \\
\text { in a peer-reviewed } \\
\text { journal, were used and } \\
\text { correctly cited. }\end{array}$ & $\begin{array}{l}\text { Less than } 4 \text { references } \\
\text { were used or there } \\
\text { were significant errors } \\
\text { in citing references. }\end{array}$ & $\begin{array}{l}\text { Less than } 4 \text { references } \\
\text { were used and there } \\
\text { were significant errors } \\
\text { in citing references. }\end{array}$ \\
\hline
\end{tabular}

Figure 4. Informational pamphlet rubric. Criteria for assessment are succinctly described in a rubric using a template provided at http://rubistar. 4teachers.org/index.php. at http:/ / rubistar.4teachers.org. The seven categories I used included content/accuracy, research summary, sponsoring organization, organization/originality, graphics/pictures, writing/organization, and bibliography. Categories can be specific to a particular aspect of the assignment, i.e., the research summary, or they can be generalized, i.e., writing/ organization. For each category, an instructor can write appropriate descriptors, or use prewritten descriptors provided on the Web site, that correspond to a particular letter grade. I also made reduced sized copies of the rubric, along with room for comments. At the completion of the project, each student received an individual copy of the rubric in which I indicated what level was achieved for each category, additional written comments, and an overall grade for the assignment, thus providing constructive and consistent feedback to all students.

\section{PROJECT IMPLEMENTATION}

Students explored the neurodegenerative disease ALS through scientific and nonscientific reading assignments. First, students read Tuesdays with Morrie: An Old Man, A Young Man, and Life's Greatest Lesson (Albom, 1997), and subsequently each student wrote a reaction essay that articulated whether and how the book changed her/his perspectives on life and death. The assignment was structured so that students would not simply provide a summary of the story but rather would consider the literature in relation to their own personal experiences. This reflection set the stage for students to examine science beyond the discipline and recognize the impact it has on individual lives and society as a whole. There was no right answer in this assignment, but students did need to demonstrate reflective thinking in their essays. Students confronted difficult issues and articulated their own personal philosophies. Excerpts from students' essays are provided in Box 1.

Box 1. Student Responses. Excerpts of students' responses demonstrate the reflective thinking used in their reaction essays.

"As a society, we often associate 'life' with movement and I believed before reading this book that if I had lost the ability to freely move and be able to do the 'little things' that are often taken for granted, I would not want to live much longer. .." 
"However, if you are not confronting death, most people are not as receptive to your epiphanies ... I also find it uncommon for people of my generation to take responsibility for anything, even if it is very clearly a direct result of their actions ..."

"The majority at large has a very weak understanding of the concept of awareness. While there is a significant lack of global or local awareness, more disheartening is the lack of self-awareness. Very few individuals can wholeheartedly say they know what they want from life or what they are truly made of ..."

The literature was assigned early in the semester and provided some context for the science to come. In class, we studied motor neuron function, reflexes, and motor circuits. Once basic molecular, cellular, and circuit mechanisms were understood, students had opportunities to apply the information in problem-solving scenarios. Students read journal articles and compared the symptoms and underlying pathophysiology of a variety of motor system disorders and used this clinical information to better comprehend normal function. In addition, students were presented with hypothetical scenarios and then made predictions about potential symptoms/outcomes. All of these exercises reinforced the main concepts of cell-to-cell communication and motor pathways while also providing students with opportunities to develop critical thinking skills. In addition, several readings focused on the issue of assisted suicide (Ganzini et al., 1998; Poenisch, 1998; Rowland, 1998). Exploration of this topic led to extensive class discussion regarding the ethical implications of scientific advances. Students voiced and heard varying opinions on the issue and gained skills in evaluating information and defending arguments.

Next, students created unique ALS informational pamphlets that demonstrated their understanding of concepts within the context of an appropriate sponsoring organization (for example, neurologists, hospice care providers, proeuthanasia group, and support group for caregivers) and taking into consideration their target population. Students selected a variety of perspectives when creating their pamphlets. Most students opted for a sponsoring organization in the healthcare field and targeted patients. However, some chose to focus on caregivers, family members, or both. One student created a bilingual pamphlet and focused on minority populations in the healthcare system. Despite varying perspectives, all pamphlets had to supply basic information about the disease. In addition, students provided a summary of a recent research study from primary literature in their pamphlets. Students identified the hypothesis being tested, described the basic methodology, and reviewed the main findings. Students had to critically analyze the work and judge the significance of the study.

Students produced pamphlets that demonstrated originality and conveyed their understanding of the content material. Furthermore, the pamphlet format required students to be both creative and succinct when conveying information. All students created their pamphlets on the computer using common software (Microsoft Word, Microsoft FrontPage, and Adobe PageMaker were most often used). Students mixed text with graphics, provided appropriate headings, and used colors and symbols to give the pamphlets a professional appearance.

\section{ANALYSIS OF STUDENT LEARNING}

Data were collected during two separate semesters when the course was taught. The project group ( $\mathrm{n}=18$ students) represents data collected during a semester when the project was incorporated into the course as described above. The control group ( $\mathrm{n}=13$ students) represents data collected during a semester when the project was not used in the course.

To determine whether acquisition of content knowledge is affected by inclusion of the project, scores on exam questions relating to motor system content were compared for the two groups. Students had to answer the same questions on the motor system as part of the cumulative final (Sample Exam Questions, see Supplemental Material). Because it is the final, these exams are not returned to the students, so I was confident that students in the subsequent semester had no unfair advantage. As can be seen in Figure 5, the average student score for both groups was close to the same, with an average of $70 \%$ for the project group (range 50-94\%) and a slightly higher average of $72 \%$ for the control group (range $54-100 \%)$.

Every student in the project group indicated in his/her essay that reading the nonscientific literature as part of their neurobiology class had a significant impact on their view of life and death. Many of the students said the reading had changed their perspective on certain issues, whereas others wrote that their perspectives were reaffirmed and strengthened. Using examples from the book as well as knowledge gained during the semester, students made connections with their own lives. To provide some comparison, students in the control group were asked to complete a writing assignment in which they discussed whether and how their perspective on life and death had changed as a result of taking the course (no literature component was included). Interestingly, nearly one-half of the class (42\%) indicated either that their views had not changed at all or only slightly. One-half the students in the control group thought the course had a moderate impact, and only one student felt the course had made a significant impact on his/her perspective.

There are many moral and ethical questions surrounding scientific advances, medical practices, and human behavior that are relevant to neuroscience. The issue of assisted suicide was raised as students researched ALS in the process of creating their pamphlets. We read scientific papers, personal stories, and news articles that dealt with the subject from varying perspectives. The information sparked extensive in-class discussions about disease processes, individual's rights, and society's responsibilities. I observed that the students in the project group were eager to debate these issues with their peers and that they even requested that additional class time be given to the discussion. The majority of students in the project group indicated that they found the in-depth examination of assisted suicide from multiple perspectives a valuable component of the course. In contrast, although I raised moral and ethical questions during class time with the control group, the discussions were limited, with only a few students contributing views. When students 


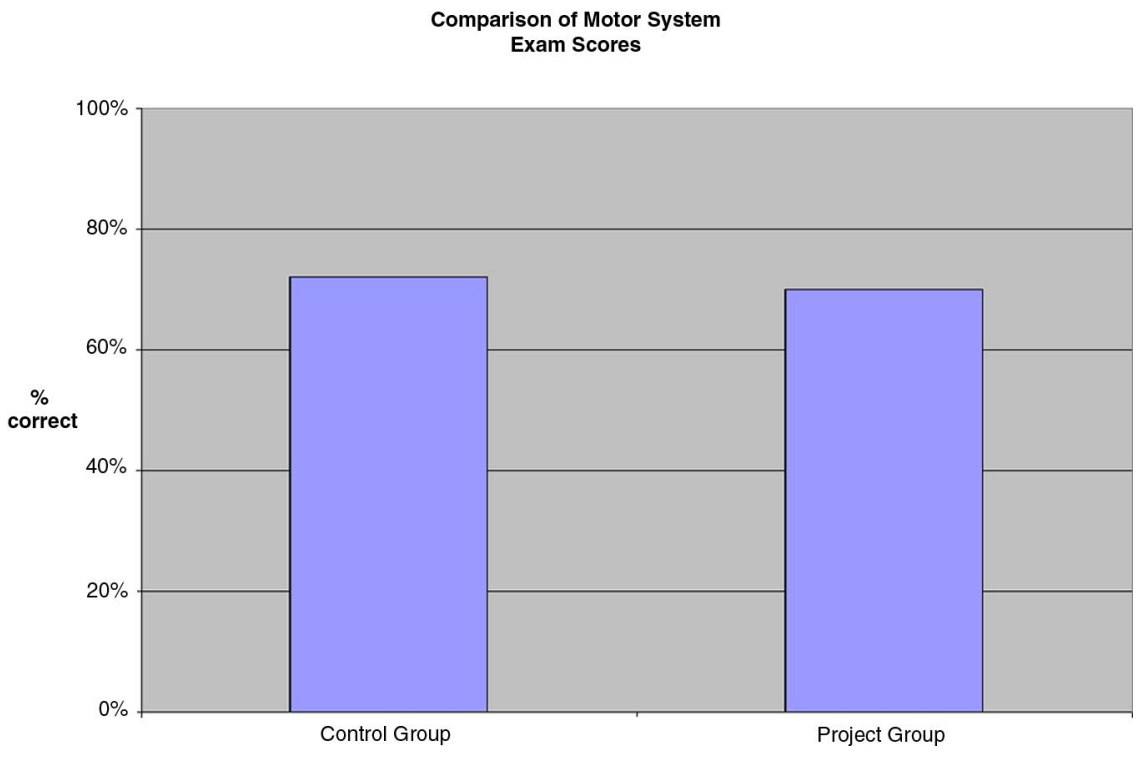

Figure 5. Comparison of exam scores. Students in the control group and project group had approximately the same average on exam questions dealing with motor system content. in the control group were asked whether they had opportunities to explore the ethical implications of scientific advances in this course, only one student thought there were many opportunities, and nearly one-half of the class (40\%) responded that there were few opportunities provided.

\section{DISCUSSION}

In a single classroom, a teacher is confronted with students who have varied learning styles (Gardner, 1983; Fedler and Silverman, 1988). It is imperative that science educators seek diverse teaching methodologies and assessment tools to effectively reach all kinds of students (Tanner and Allen, 2004). Research indicates that the traditional pedagogical styles characteristic of most introductory science courses may contribute to student attrition in science programs and poor comprehension of basic scientific concepts (Tobias, 1990; Seymour and Hewitt, 1997; Hake, 1998; Fagan et al., 2002). In keeping with a constructivist approach (Vygotsky, 1978), this semester-long project incorporates literature, individual student interests, clinical information, and basic science content knowledge to enrich the learning environment for an entire class. The different components of this project are distributed throughout the semester and foster meaningful discussions relevant to the scientific topics being explored. Furthermore, the tasks address learning outcomes universal to any (neuro)biology program and yield evidence-based assessments in keeping with scientific reform initiatives.

One of the advantages of this project is that an instructor can modify it as needed. Importantly if one begins by delineating the student learning outcomes, then these goals can guide the entire planning process (Wiggins and McTighe, 2005). I chose to focus on the motor system and ALS as the associated neurological condition, and I selected a relevant book for required reading, but this is just one of many possible scenarios. The majority of learning outcomes could be met by focusing on an entirely different aspect of the nervous system. In addition, the informational pamphlet could focus on nervous system function, rather than dysfunction. For example, the pamphlet could be modeled after Brain Backgrounders and Brain Briefings, which are short narratives published by the Society for Neuroscience that are designed to inform the public about our current understanding of specific aspects of brain function and to delineate links between basic research and clinical advances (http://web.sfn.org). Students could construct informational pamphlets on any neuroscience topic (e.g., glia, chemical synapses, and memory) and include facts, data analysis, and resource information. What is more important than the topic per se is that the project provides opportunities for students to develop critical thinking skills, to explore a particular topic in depth, and to recognize the interactions between science and society. Although I have not had any problems with plagiarism, altering the literature and focus topic during different semesters could reduce the risk of this happening. The potential for plagiarism is also reduced by having students choose a particular perspective when creating their pamphlet because this helps personalize the project and makes each pamphlet unique. When students brought their pamphlets to class, they were interested to see what their peers had created. It could be useful to plan a more structured review of pamphlets among peers.

Summative assessments typically evaluate end products, and they are used to arrive at a particular grade for each student. Common summative assessments used in science courses are exams, factual essays, and laboratory reports. This project uses two summative assessment tools that are not typically found in science courses-a reaction essay requiring personal reflection (rather than a factual summary) and an information pamphlet designed from a particular perspective chosen by the student. In my neuroscience course, these innovative techniques complement the traditional exam-based assessments that account for the majority of the student's final course grade. The project grade was given the same weight as one exam grade when deter- 
mining final grades. Thus, the students did recognize that the project was a significant component that required their attention. Furthermore, by offering the students some alternative assessments, they had multiple opportunities to demonstrate their mastery of important learning outcomes. Because it is the responsibility of the instructor to engage every student, many with different learning styles and strengths, this diversity of assessment is crucial (Walvoord and Anderson, 1998; Tanner and Allen, 2004). For example, a student who has done mediocre exam work and has trouble with test anxiety now has additional chances to succeed. I also made use of in-class discussion and group problem-solving exercises related to the project at different points in the semester as formative assessment tools. These activities helped to motivate the students and allowed me to monitor student learning. Because students enter the classroom with preconceived ideas (both correct and incorrect) that must be recognized by the instructor and student alike, it is important to get feedback and then respond proactively to make necessary changes in instruction before administering summative assessments (Posner et al., 1982; Tanner and Allen, 2005).

It is difficult enough determining what scientific content to include/exclude in a one-semester course. At first, it may seem impossible or detrimental to add a literature segment, particularly if it is seen as taking away from the science. Thus, student exam scores were recorded over two semesters-one semester when the project was included in the course and one semester when the project was not incorporated. As a caveat, there are many variables that could affect group averages when examining grades from a heterogeneous population of students. This being said, a comparison of exam scores demonstrates that both groups had approximately the same average and same range of scores, thus indicating that retention of content material was equivalent at the end of the semester. What did the students in the project group gain? The project was designed to address multiple learning outcomes and to create measurable parameters of learning (Figure 3). Several of the learning outcomes are not content specific; rather, they reflect skills that a student should develop across the college curriculum to set the stage for lifelong learning. The open-ended nature of the project requires students to apply the content knowledge and problem-solve by using many higher-level thinking skills. The reaction essay and pamphlet are products that can be assessed to evaluate whether particular outcomes are met. In addition, this project may be particularly helpful to achieve specific goals often overlooked in traditional science courses, such as the impact of science on society and ethical considerations. For example, readings associated with ALS served as an excellent springboard for discussions of moral and ethical questions associated with end-of-life issues. Rather than dealing with science as an isolated entity, this project allows for a more formal, systematic approach to incorporate multiple disciplines and other ways of thinking about a topic. Interestingly, the students in the project group recognized the impact science has on society and individual lives. In contrast, when students in the control group reflected on the content in the course, they did not make these same connections. Thus, inclusion of the project did not dilute the science, but rather it enriched the science by putting it in a context relevant to the students' lives. Story- telling is an excellent teaching tool and is used extensively with case study methodologies (Herreid, 2005). The literature incorporated into this project provides a story that captivates students' attention, personalizes the topic, and subsequently motivates students to understand the relevant science from multiple perspectives.

National scientific bodies/agencies are calling for significant improvements in methods of teaching and assessment (American Association for the Advancement of Science, 1993; National Research Council, 2002). In addition, science educators who have successfully revamped courses and programs are now reverberating the call (Hake, 1998; Handelsman et al., 2004). Proponents of science education reform seek to promote meaningful learning that relates to the real world rather than rote memorization of isolated facts and figures. Such learning is critical to both the science major and the nonscience major alike. Any student wishing to pursue a career in a science-related field needs to acquire a strong knowledge base and to develop a diverse repertoire of analytical skills. Just as important, with the pervasiveness of science and technology in the world today, it can be argued that for an individual to make informed decisions (e.g., regarding public policy, personal health choices, and so on), he/she needs a clear understanding of unifying scientific concepts along with the ability to problem-solve. This project weaves together multiple pedagogical strategies and provides opportunities for students to develop critical thinking skills. It requires both individual reflection along with collaborative work. The alternative assessments provide authentic measures of wide-ranging learning outcomes. By incorporating literature and innovative pedagogy in introductory courses, a science educator can persuasively illustrate the power and excitement of science and spark the interests of a diverse student body.

\section{REFERENCES}

American Association for the Advancement of Science (1993). Benchmarks for Science Literacy. Washington, DC. http:// www.project2061.org/publications/bsl/online/bolintro.htm (accessed 1 July 2005).

American Association for Higher Education (1992). Principles of good practice for assessing students learning. Washington, DC.

Albom, M. (1997). Tuesdays with Morrie: An Old Man, A Young Man, and Life's Greatest Lesson, New York: Bantam Doubleday Dell Publishing Group, Inc.

Angelo, T. A. (1995). Reassessing and defining assessment. AAHE Bull. 51, 3-6.

Battistoni, R. (1995). Service learning, diversity, and the liberal arts curriculum. Lib. Educ. 81, 30-35.

Bloom, B. S., and Krathwohl, D. R. (1956). Taxonomy of educational objectives: the classification of educational goals by a committee of college and university examiners. In: Handbook 1: Cognitive Domains, New York: Longmans, Green.

Fagan, A. P., Crouch, C. H., and Mazur, E. (2002). Peer instruction: results from a range of classrooms. Phys. Teach. 40, 206-209.

Fedler, R. M., and Silverman, L. K. (1988). Learning and teaching styles in engineering education. Eng. Educ. 78, 674-681.

Ganzini, L., Johnston, W. S., McFarland, B. H., Tolle, S. W., and Lee, M. A. (1998). Attitudes of patients with amyotrophic lateral sclerosis 
and their care givers toward assisted suicide. N. Engl. J. Med. 339, 967-974.

Gardner, H. (1983). Frames of Mind: The Theory of Multiple Intelligences, New York: Basic Books.

Hake, R. R. (1998). Interactive-engagement versus traditional methods: a six-thousand-student survey of mechanics test data for introductory physics. Am. J. Phys. 66, 64-74.

Handelsman, J., et al. (2004). Scientific teaching. Science 304, 521522.

Heady, J. E. (2000). Assessment - a way of thinking about learning - now and in the future. J. Coll. Sci. Teach. 29, 415-421.

Herreid, C. F. (2005). Using Case Studies to Teach Science, Washington, DC: American Institute of Biological Sciences.

Hobson, A. (2001). Teaching relevant science for scientific literacy. J. Coll. Sci. Teach. 30, 238-243.

Krathwohl, D. R, Bloom, B. S, and Masia, B. B. (1964). Taxonomy of Educational Objectives: The Classification of Educational Goals. Handbook II: Affective Domain, New York: David McKay Co., Inc.

Lynd-Balta, E., Erklenz-Watts, M., Freeman, C., and Westbay, T. D. (2006). Professional development using an interdisciplinary learning circle. J. Coll. Sci. Teach. 35, 18-23.

Montgomery, K. (2002). Authentic tasks and rubrics: going beyond traditional assessments in college teaching. Coll. Teach. 50, 34-39.

National Research Council (2002). BIO 2010, Undergraduate Education to Prepare Biomedical Research Scientists, Washington, DC: The National Academies Press.
Poenisch, C. (1998). Merian Frederick's story. N. Engl. J. Med. 339, 996-998.

Posner, G. J., Strike, K. A., Hewson, P. W., and Gertzog, W. A. (1982). Accommodation of a scientific conception: towards a theory of conceptual change. Sci. Educ. 66, 211-227.

Rowland, L. P. (1998). Assisted suicide and alternatives in amyotrophic lateral sclerosis. N. Engl. J. Med. 339, 987-989.

Seymour, E., and Hewitt, E. (1997). Talking About Leaving: Factors Contributing to High Attrition Rates among Science, Mathematics, and Engineering Undergraduate Majors, Boulder, CO: Bureau of Sociological Research.

Tanner, K., and Allen, D. (2004). Approaches to biology teaching and learning: learning styles and the problem of instructional selection - engaging all students in science courses. Cell Biol. Educ. 3, $1-7$.

Tanner, K., and Allen, D. (2005). Approaches to biology teaching and learning: understanding the wrong answers - teaching toward conceptual change. Cell Biol. Educ. 4, 1-8.

Tobias, S. (1990). They're Not Dumb, They're Different: Stalking the Second Tier. Tucson, AZ: Research Corporation.

Vygotsky, L. (1978). Mind in Society, Cambridge, MA: Harvard University Press.

Walvoord, B. E., and Anderson, V. J. (1998). Effective Grading: A Tool for Learning and Assessment, San Francisco: Jossey-Bass.

Wiggins, G., and McTighe, J. (2005). Understanding by Design, Alexandria, VA: Association for Supervision and Curriculum Development. 